UDC $629.7(045)$

DOI 10.18372/2306-1472.88.15988

Volodymyr Kharchenko ${ }^{1}$

Hanyeh Bahmanfar ${ }^{2}$,

Alexander Onishchenko ${ }^{3}$

\title{
APPROACH TO EVALUATION OF THE APPLICATION AND EFFICIENCY OF STRATOSPHERE UAV
}

\author{
${ }^{12} 3$ National Aviation University, 1, Liubomyra Huzara ave.Kyiv, Ukraine 03058 \\ E-mails: ${ }^{1}$ kharch@nau.edu.ua, ${ }^{26}$ armaley@i.ua
}

\begin{abstract}
The article considers the theoretical aspects of UAV research for flights in the stratosphere, analyzes the approaches to evaluating the use and effectiveness of UAVs. Measures have been developed to optimize the use of UAV data. The purpose of the article is to analyze the features of the development of methods for evaluating the effectiveness of stratospheric UAVs, as well as measures to optimize this category of drones.
\end{abstract}

Keywords: artificial intelligence, UAV, programming, intelligent technologies, stratosphere, evaluation methods.

\section{Introduction}

Today in the process of UAV operation there are different stages, different subsystems, devices and modes of their operation are used, different operations are performed. In this regard, the system performance indicators of UAVs can be assessed by a wide range of parameters. As practice shows, there are approaches: to evaluate the effectiveness of UAVs, to evaluate the use of UAVs and combined - approaches to simultaneously evaluate the effectiveness of UAVs and the effectiveness of UAVs. It should be noted that the wide range of UAVs, their different levels of technological and technical level bring to the fore the task of their comparative evaluation and evaluation of their effectiveness, as the basis of the decision-making process in the formation of a modern UAV fleet.

Thus estimation of efficiency of the UAV can be realized: on the basis of a complex indicator of efficiency; by individual performance indicators; through the use of comprehensive evaluation and evaluation of individual performance indicators. The novelty of the study lies in the analysis of the features of the development of methods for evaluating the effectiveness of UAVs. In addition, the development of methods for evaluating the effectiveness of UAVs will solve the issue of reasonable formation of tactical and technical requirements for newly created UAVs at the stage of writing a tactical and technical task for R \& D;

comparison of different types of UAVs; determining the conditions of use in which the effectiveness of the UAV tends to the maximum; development of measures for optimal (rational) use of UAVs.

\section{The main part}

In this case, the algorithm for evaluating the effectiveness of UAVs and the processes of their application can be implemented: on the basis of a comprehensive efficiency indicator; by individual performance indicators; through the use of comprehensive evaluation and evaluation of individual performance indicators. The necessity of development of a technique of estimation of efficiency of stratospheric UAVs is defined. Currently, there is a need to develop a basic mathematical model for evaluating the effectiveness of stratospheric UAVs.

The basic model of the UAV, adequately reflects its aerodynamic characteristics, taking into account the limitations and assumptions adopted during the development of this model. In addition, the basic model allows to evaluate the efficiency of the UAV according to the experimental dependences for pitch angle, speed, thrust, battery charge and the coefficient that determines the ratio of charge to battery 
capacity as a function of time. At the same time, the basic mathematical model for evaluating the effectiveness of UAVs in order to expand its own functionality involves a number of modifications.

The proposed modification of the basic mathematical model of stratospheric UAVs allows to build automated algorithms for estimating UAV parameters and to organize the procedure for evaluating efficiency through the analysis of such dependences as the ratio of lifting force to angle of attack and drag coefficient, lifting ratio specific power from the load on the wing height of the aircraft UAS. Further modifications of the basic model are related to taking into account: the parameters of the UAV power supply system; algorithms for optimal electricity distribution; features of UAV operation; factors related to the external environment and affecting the level of electricity consumption.

Let's analyze the main examples of application of the above approaches to assessing the effectiveness of UAVs:

$$
\mathrm{k}_{\mathrm{ee}}=\frac{\mathrm{V}_{\mathrm{ek}} \mathrm{T}_{\max }}{0,318 \overline{\mathrm{E}}_{\Gamma \Pi}}
$$

- the maximum coefficient of efficiency of the UAV with electric power plant;

- economic speed;

- maximum flight duration;

- relative energy reserve for horizontal flight.

The proposed comprehensive indicator can be especially useful in solving problems of assessing the technical excellence of existing models of unmanned platforms for different types of target loads and unmanned platforms, as well as when used as part of integrated indicators during the development of concepts of modern UAVs [1]. The main disadvantages of this comprehensive indicator are: obtaining approximate estimates of the level of technical perfection of UAVs with power plant; complicating the calculations of this indicator with increasing altitude. When creating an efficient UAV on solar cells, it is necessary to strive to reduce energy needs and increase aerodynamic performance. It is proposed to use the criterion of UAV perfection in the form of [2]:

$$
K(\mathrm{~K} 1, \mathrm{p}, \mathrm{V}, \overrightarrow{\mathrm{W}})=\frac{\mathrm{p}, \mathrm{V}, \overrightarrow{\mathrm{W}}}{\mathrm{K}}=\frac{\mathrm{VW}_{\mathrm{l}}}{\mathrm{S}_{\mathrm{s}}},(
$$

$\mathrm{K}$ - coefficient of aerodynamic perfection;

p-load on the wing;

V- flight speed;

$\overline{\mathrm{W}}$ - specific power consumption;

$W_{l}$ - the necessary power for the flight;

$S_{S}-$ wing area.

It should also be considered as a partial criterion that determines the effectiveness of stratospheric UAVs. These include the following [3]: Performance, flight duration, time efficiency, relative weight, target load take-off weight, scope, resolution, coverage, cost, risk.

These criteria are used to select concepts for the construction of stratospheric UAVs, which differ in: aerodynamic scheme (normal scheme, "flying wing", articulated wings); energy sources (expendable and non-expendable energy sources); engine (internal or external combustion, electric motor); by the method of energy conversion transmitted from the source to the propulsion [4].

To solve the problem, the method of confident judgments is used, which assumes that for a comprehensive assessment of the effectiveness of the alternative on the basis of normalized values of its individual criteria, a convolution of these criteria (linear or maximum (Hermeyer)) is used. It is based on the definition of hard and soft ratings of alternatives by formulas, respectively [5]:

$$
\begin{aligned}
& \mathrm{R}_{\mathrm{i}}=\int_{\mathrm{s} \in \mathrm{Q}} \mathrm{ds} / \int_{\mathrm{s} \in \mathrm{S}} \mathrm{ds} \\
& \mathrm{Q}=\left\{\mathrm{s} \in \mathrm{S}, \mathrm{F}_{\mathrm{S}}\left(\mathrm{f}_{\mathrm{i}}\right) \leq \mathrm{F}_{\mathrm{s}}\left(\mathrm{f}_{\mathrm{k}}\right), \mathrm{k}=\overline{1, \mathrm{n}}, \mathrm{k} \neq \mathrm{i}\right\}, \mathrm{i}=\overline{1, \mathrm{n}} ; \\
& \mathrm{AR}_{\mathrm{i}}=1-\left(\frac{\int_{\mathrm{s} \in \mathrm{S}} \mathrm{F}_{\mathrm{S}}\left(\mathrm{f}_{\mathrm{i}}\right) \mathrm{ds}}{\int_{\mathrm{s} \in \mathrm{S}} \mathrm{ds}}\right), \mathrm{i}=1, \ldots, \mathrm{n} \\
& \mathrm{S}-\text { the set of allowable values of weights; } \\
& \mathrm{s}-\text { subset of the set } \mathrm{S} ; \\
& \mathrm{R}_{\mathrm{i}}-\text { hard rating alternative; } \\
& \mathrm{AR}_{\mathrm{i}} \text { - soft rating of the alternative. }
\end{aligned}
$$

It should be noted that the main disadvantage of this approach is the low accuracy compared to methods that use accurate numerical rather than vague values of weights [6].

Because the effectiveness of the UAV depends on both the tactical and technical characteristics of the 
device, and the capabilities of the elements of the onboard complex of the UAV and ground components. In addition, changes in the conditions of optical visibility, electronic environment, as well as the presence of resistance in the area of the UAV significantly reduce the effectiveness of its application.

Consider the method of evaluating the effectiveness of UAVs for environmental monitoring. To assess the effectiveness of the use of the drone, we use the probability of performing a flight task by a search UAV [7]:

$$
P_{p}=P_{a} P_{b} P_{c} P_{d} P_{k} P_{l}(1.5)
$$

$P_{a}$ - the probability that the UAV will be serviceable throughout the flight or the level of its serviceability will not affect the task;

$P_{b}$ - the probability that the UAV will enter the search area;

$P_{c}-$ the probability of overcoming adverse effects in the executive zone and when approaching it (for civilian UAVs - is the probability of overcoming such factors as bad weather conditions, as well as factors affecting the UAV in the case of its use in areas of natural disasters and man-made disasters) $[8$ ]:

$$
\mathrm{P}_{\text {пнв }}=\mathrm{e}^{-\sum_{\mathrm{i}=1}^{\mathrm{N}} \lambda_{\mathrm{i}} \mathrm{t}_{\mathrm{ni}}},
$$

$\lambda_{i}$ - the intensity of the effective influence of the $\mathrm{i}$-th adverse factor $\mathrm{A}$;

${ }^{t_{n i}}$ - the time of the UAV in the area of direct influence of the $\mathrm{i}$-th adverse factor;

$P_{l}$ - the probability that the information transmitted to the consumer will not lose its relevance in the time elapsed from the receipt of UAV information to its transmission to the consumer [9]:

$$
\text { , } P_{l}=e^{-\frac{T_{1}}{T_{2}}}(1.7)
$$

$T_{1}$ - time of data detection and transmission;

$T_{2}-$ the average time spent by the intelligence object in this state or place;

$P_{d^{-}}$probability of object detection;

$P_{k}$ - the probability of delivery of information to the consumer.

It should be emphasized that the basic mathematical model for evaluating the effectiveness of UAVs, which is taken as the basis for evaluation, should be based on the equations for lift $F_{L}$ (lift force, $\mathrm{LF}$ ), aerodynamic drag $F_{D}$ (drag force), traction $F_{T}$ (thrust force), calculated on the basis of lifting force and aerodynamic drag, as well as pitch $M_{P}$ (pitching moment, MP):

$$
\begin{aligned}
& {\left[\begin{array}{l}
F_{L}=q \cdot k_{L} \cdot S_{W} \\
F_{D}=q \cdot k_{D} \cdot S_{W} \\
M_{P}=q \cdot k_{P} \cdot l_{A F} \cdot S_{W},(1.8) \\
F_{T}=F_{L} \cdot \frac{k_{D}}{k_{L}}
\end{array}\right.} \\
& \text { де } q \text { - free flow pressure; } \\
& S_{W} \text { - total wing area; } \\
& k_{L} \text { - lifting force coefficient; } \\
& k_{D} \text { - aerodynamic drag coefficient; } \\
& k_{P} \text { - pitch factor; } \\
& l_{A C} \text { - the length of the chord of the aerodynamic }
\end{aligned}
$$
profile (airfoil chord).

Free flow pressure is determined based on air density values $\rho_{A}$ depending on the altitude of the UAV and the speed of the device $v_{U A V}$ :

$$
q=\frac{\rho_{A} \cdot\left(v_{U A V}\right)^{2}}{2} \text {. }
$$

To further model and optimize the trajectory of the UAV by mathematical methods, it is sufficient to construct differential equations to change the speed of the device $d v_{U A V} / d t$ and pitch angle $d \theta_{U A V} / d t$. To do this, the concept of angle of attack is introduced $\alpha_{U A V}$ and the angle of inclination $\vartheta_{U A V}$ and $\vartheta_{U A V}=$ $\alpha_{U A V}+\theta_{U A V}$. From these equations through the definition $\theta_{U A V}$ you can go to the navigation differential equations for $d x / d t$ i $d z / d t$, where the axis $X^{\prime} X$ - corresponds to horizontal motion UAV, a $Z^{\prime} Z$ - vertical [10]:

$$
\begin{aligned}
& {\left[\begin{array}{l}
\frac{d \theta_{U A V}}{d t}=\frac{F_{T} \cdot \sin \left(\alpha_{U A V}\right)-\left(F_{L}-P \cdot \cos \left(\theta_{U A V}\right)\right)}{m_{U A V} \cdot v_{U A V}} \\
d t
\end{array}=\frac{F_{T} \cdot \cos \left(\alpha_{U A V}\right)-\left(F_{D}+P \cdot \sin \left(\theta_{U A V}\right)\right)}{m_{U A V}}\right.} \\
& \rightarrow\left[\begin{array}{l}
\frac{d x}{d t}=v_{U A V} \cdot \sin \left(\theta_{U A V}\right) \\
\frac{d z}{d t}=v_{U A V} \cdot \cos \left(\theta_{U A V}\right)
\end{array}\right. \\
& m_{U A V}-\text { table UAV, a } P=m_{U A V} \cdot g-\text { his }
\end{aligned}
$$

Also for construction of mathematical model it is important to define the first and second derivative of an angle of inclination, as angular frequency of 
rotation. $\omega_{y}$ along the axis $Y^{\prime} Y$ and the ratio of pitch and moment of inertia $I_{y}$ :

$$
\left[\begin{array}{l}
\frac{d \vartheta_{U A V}}{d t}=\omega_{y} \\
\frac{d^{2}}{d t^{2}} \vartheta_{U A V}=\frac{M_{P}(y)}{I_{y}}
\end{array} .\right.
$$

In addition, for most tasks, the flight of a UAV can be considered as occurring during the main time in horizontal mode. in this case, the values of the angle of attack and the angle of inclination of the UAV can be considered close to zero. This significantly simplifies the differential equations for derivatives by pitch angle and velocity and can be used in the development of a mathematical apparatus to evaluate the efficiency of the subsystem of solar cells of the UAV power supply system [11]:

$$
\begin{aligned}
& {\left[\begin{array}{l}
\frac{d \theta_{U A V}^{+}}{d t} \approx \frac{F_{L}-P \cdot \cos \left(\theta_{U A V}\right)}{m_{U A V} \cdot v_{U A V}} \\
\frac{d v_{U A V}^{+}}{d t} \approx \frac{F_{T}-F_{D}-P \cdot \sin \left(\theta_{U A V}\right)}{m_{U A V}}
\end{array} \rightarrow\right.} \\
& {\left[\begin{array}{c}
\frac{d \theta_{U A V}^{+}}{d t} \approx \frac{g \cdot\left(k_{N O}-\cos \left(\theta_{U A V}\right)\right)}{v_{U A V}} \\
\frac{d v_{U A V}^{+}}{d t} \approx g \cdot\left(\frac{F_{T}-F_{D}}{P}-\sin \left(\theta_{U A V}\right)\right)
\end{array}\right.} \\
& k_{N O}=F_{L} / P-\text { normal overload coefficient }
\end{aligned}
$$
(normal overload, NO).

The specification of the constructed model according to the power supply scheme allows to optimize the trajectory of autonomous flight of the UAV using the methods of numerical analysis. Before conducting quantitative calculations, it is necessary to determine the minimum level of accuracy and maximum duration of these calculations, which corresponds to the number of iterations, and in accordance with them to build a software algorithm for evaluating the effectiveness of UAVs. To this end, it may be proposed to apply sequential quadratic programming techniques.

The proposed basic model allows to evaluate the efficiency of the UAV according to the experimental dependences for pitch angle, speed, thrust, battery charge and the coefficient that determines the ratio of charge to battery capacity as a function of time. As noted earlier, this basic model provides a number of modifications to expand its functionality.

We will consider options for improving this model, which are associated with modeling the flight of the UAV and determining its aerodynamic parameters depending on the altitude of the UAV above sea level. It is clear that when evaluating the effectiveness of the key arguments of the objective functions will be the lifting force $\mathrm{Y}$ and aerodynamic drag X, which, in turn, are determined on the basis of the following values [12]:

- coefficient of lifting force $C_{Y}$;

- drag coefficient $C_{X}$;

- air density as a function of altitude БПЛА $\rho\left(h_{U A V}\right)$

- the total area of the wings of the UAV $-S_{W}$;

- the relative speed of the UAV $-v_{U A V}$.

The values of the coefficient of lift and drag coefficient depend on the aerodynamic profile of the UAV, the angle of attack and the Reynolds number Re. The basis of mathematical modeling at this stage are the indicators of lift and aerodynamic drag:

$$
\left[\begin{array}{c}
Y=C_{Y} \cdot \frac{\rho\left(h_{U A V}\right) \cdot\left(v_{U A V}\right)^{2}}{2} \cdot S_{W} \\
X=C_{X} \cdot \frac{\rho\left(h_{U A V}\right) \cdot\left(v_{U A V}\right)^{2}}{2} \cdot S_{W} \\
Y=\frac{C_{Y} \cdot X}{C_{X}} .
\end{array}\right.
$$

To calculate the lift coefficient of the UAV, the aerodynamic profile of the wing is proposed to be modeled at the level of a two-dimensional problem. At the same time the calculation $C_{X}$ is more nontrivial, it is necessary to determine the coefficient of drag $C_{A D}$ (airfoil drag, AD), which can also be calculated for a two-dimensional model of the aerodynamic profile, the coefficient responsible for the component of parasitic resistance $C_{P D}$ (parasitic drag, PD) and is determined experimentally, as well as inductive resistance $C_{I D}$ (induced drag, ID). The inductive resistance is calculated on the basis of the coefficient of lift and the relative elongation of the wing $k_{A R}$ (aspect ratio, AR). Based on these indicators, the drag coefficient is calculated as the sum of:

$$
C_{X}=C_{A D}+C_{P D}+\frac{\left(C_{Y}\right)^{2}}{k_{e} \cdot k_{A R}}
$$

Where the coefficient $k_{e}$ based on the efficiency coefficient of Oswald, for stratospheric UAVs $k_{e} \approx$ $\pi$. The adequacy of the proposed mathematical apparatus and its improvement in accordance with the specific task of building a UAV should be further verified on the basis of experimental tests, such as through the use of a wind tunnel. Further work on 
modeling the UAV leads to the introduction of the concept of thrust of the aircraft $\mathrm{T}$, and determination based on the value of the total mass m_UAV of its speed [13]:

$$
\begin{gathered}
v_{U A V}= \\
2 \sqrt{\left(m_{U A V} \cdot g\left(h_{U A V}\right)\right) /\left(\rho\left(h_{U A V}\right) \cdot S_{W} \cdot C_{Y}\right)} .
\end{gathered}
$$

The value of the speed of the UAS can be used as a basis for calculating the power used in the horizontal flight mode of the device (level flight, LF):

$$
\begin{gathered}
P_{L F}=T \cdot v_{U A V} \rightarrow P_{L F}=\frac{Y \cdot C_{X} \cdot v_{U A V}}{C_{Y}} \rightarrow P_{L F}= \\
C_{X} \cdot \sqrt{\frac{2}{s_{W} \cdot \rho\left(h_{U A V}\right)} \cdot\left(\frac{m_{U A V} \cdot g\left(h_{U A V}\right)}{C_{Y}}\right)^{3}}
\end{gathered}
$$

Accordingly, the specific power (power density, PD) for horizontal flight can be calculated as a ratio $P_{L F}$ i $S_{U A V}$ :

$$
P_{L F}^{P D}=C_{X} \cdot \sqrt{\frac{2}{\rho\left(h_{U A V}\right)} \cdot\left(\frac{m_{U A V} \cdot g\left(h_{U A V}\right)}{S_{W} \cdot C_{Y}}\right)^{3}}
$$

It should be noted that the dependence $P_{L F}^{P D} \sim\left(\rho\left(h_{U A V}\right)\right)^{-\frac{1}{2}}$ allows for different heights of horizontal flight to build the dependence of the load on the wing $P_{L F}^{P D}$ in accordance with the specific design features of the UAV.

An indicator that characterizes the stratospheric UAV in accordance with the ability to assess its effectiveness is the coefficient of bearing capacity $C_{M}$, which is calculated as the ratio of the mass of the main part of the UAV (constant mass) $-M_{C}$ and the mass of the elements to be optimized during the completion of the device, ie the wings and solar panels that cover them $-M_{W}$ (total weight $M_{\Sigma}=$ $\left.M_{\mathrm{C}}+M_{W}\right)$.

It is advisable to determine $M_{W}$ as the product of the density index $\rho_{-} \mathrm{W}$ and the total wing area of the UAV [14]:

$$
C_{M}=\frac{M_{\Sigma}-\rho_{W} \cdot S_{W}}{M_{\Sigma}}
$$

As shown by the results of practical research for successful series of UAVs indicator $C_{M}$ is a fixed value that lies within $C_{M} \in[0,15 ; 0,22]$.

The approach was applied to design in the zero approximation.

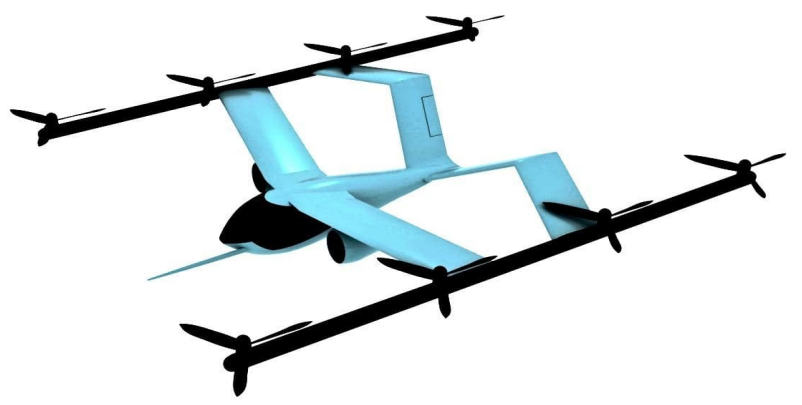

Figure 1. Carrying out the technique on the UAV

\section{Conclusions}

The rather extensive nomenclature of UAVs, their multilevel technological and technical level bring to the fore the task of evaluating their effectiveness as the basis of the decision-making process during the formation of a modern UAV fleet. It is obvious that the design of the methodology for evaluating the effectiveness of UAVs is required in order to: reasonably form the tactical and technical requirements for the newly created UAS at the stage of writing a tactical and technical task for R \& D; comparison of different types of UAVs; determining the conditions of use in which the effectiveness of the UAV tends to the maximum; development of measures for optimal (rational) use of UAVs.

In this case, the algorithm for evaluating the effectiveness of UAVs and the processes of their application can be implemented: on the basis of a comprehensive efficiency indicator; by individual performance indicators; through the use of comprehensive evaluation and evaluation of individual performance indicators. The necessity of development of a technique of estimation of efficiency of stratospheric UAVs is defined. Currently, there is a need to develop a basic mathematical model for evaluating the effectiveness of stratospheric UAVs.

The basic model of the UAV, adequately reflects its aerodynamic characteristics, taking into account the limitations and assumptions adopted during the development of this model. In addition, the basic model allows to evaluate the efficiency of the UAV according to the experimental dependences for pitch angle, speed, thrust, battery charge and the coefficient 
that determines the ratio of charge to battery capacity as a function of time.

At the same time, the basic mathematical model for evaluating the effectiveness of UAVs in order to expand its own functionality involves a number of modifications. The proposed modification of the basic mathematical model of stratospheric UAVs allows to build automated algorithms for estimating UAV parameters and to organize the procedure of efficiency evaluation through the analysis of such dependences as the ratio of lift coefficient to angle of attack and drag coefficient.

The ratio of lifting force and aerodynamic drag as a function of drag coefficient, the dependence of specific power on the load on the wing height

\section{References}

1. Barsov V.I. (2008) The concept of creating an information processing system for unmanned aerial vehicles based on the use of modular arithmetic // Elektroinform. - № 4. - P. 9-11.

2. Bencafo A.S. (2014) Performance indicators of unmanned aerial vehicles. Systems analysis and applied computer science. 1-3.- P. 17-22.

3. Ventzel E.S. (1999) Probability theory: A textbook for universities. - 6th type. ster. - M .: Higher school, - P. 12-54.

4. Verba V.S, Tatarsky B.G. (2016) Complexes with unmanned aerial vehicles. In 2 books. M .: Radio engineering, - $1352 \mathrm{p}$.

5. Galushkin A.I .(2010) Theory of neural networks. / M .: IPRZHR ,. - P. 319-328.

6. Kondratenkov G.S. (2015) Aviation radio systems: a monograph. M .: Radio Engineering, $-648$

7. Merkulov VI, Drogalin VV, Kanashchenkov AI (2003) and others. Aviation radio control systems. Volume 1. Principles of construction of radio control systems. Fundamentals of synthesis and analysis. M .: Radio Engineering, - $192 \mathrm{p}$

8. Moiseev V.S, Tutubalin P.I. (2011) On the problem of information security of unmanned aerial vehicles // VI International Scientific and Technical Conference «Problems and prospects of the aircraft UAS. Further modifications of the basic model are related to taking into account: the parameters of the UAV power supply system; algorithms for optimal electricity distribution; features of UAV operation; factors related to the external environment and affecting the level of electricity consumption.

Thus, the proposed modification of the basic mathematical model of stratospheric UAVs allows to build automated algorithms for estimating the parameters of this type of drones and organize the procedure for evaluating efficiency through the analysis of such dependences as the ratio of lifting force to angle of attack coefficient of drag, the dependence of specific power on the load on the wing height of the UAV of the aircraft.

for the development of aviation, ground transport and energy». - Vol. 2. - P. 324-331.

9. Pavlov O.M. (2001) Principles of organization of onboard measuring systems of advanced aircraft // The world of computer automation. - № 4. - P. 3-8.

10. Pantenkov DG, (2019) Lomakin OO Estimation of endurance of the satellite control channel of unmanned aerial vehicles in the event of interference // Radio Engineering. - Vol. 83. № 11 (17). - P. 43-50

11. Predachenko KO, Lemko OL (2015) Estimation of aerodynamic efficiency of an aircraft with a wing of complex spatial configuration. Scientific and technical conference of teachers, scientists, graduate students and students, dedicated to the Day of Science. Pp. 191-194.

12. Silkov VI, Zhdanov SV, Delas MI (2013) Express assessment of technical excellence of unmanned aerial vehicles based on its flight data. Science and defense. \№ 3. - P. 45-50.

13. Sklyar B. (2003) Digital communication. Theoretical foundations and practical application: Per. from English M .: Williams,. - 1104 c.

14. Stratiy A.V. (2015). Consolidation of information flows in air navigation services systems // XV International scientific-practical conference of young scientists and students «Flight. Modern problems of science», thesis add. - K .: NAU, 2015. - P. 90-98. 


\section{В.П. Харченко ${ }^{1}$ Баманфар Ханісх ${ }^{2}$, О.А. Онишенко ${ }^{3}$}

Методика оцінюваня ефективності стратосферних безпілотних літальних апаратів

${ }^{2}$ Національний авіаційний університет, просп. Любомира Гузара, 1, Київ, 03058, Україна

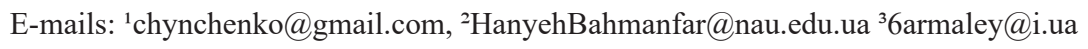

У статті розглянуті теоретичні аспекти дослідження БПЛА для польотів в стратосфері, визначено особливості застосування нейронних мереж для розроблення методики оиінювання їх ефективності. Проаналізовано алгоритм функиіонування стратосферних БПЛА в заданих умовах. Розроблено заходи щзодо оптимізащії використання даних БПЛА.

Ключові слова: нейронні мережі, штучний інтелект, БПЛА, програмування, інтелектуальні технологіï, стратосфера.

\section{В.П. Харченко ${ }^{1}$ Баманфар Ханиех ${ }^{2}$, О.А. Онишенко ${ }^{3}$}

Методика оценки эффективности стратосферных беспилотных летательных аппаратов

${ }^{2}$ Национальный авиационный университет, просп. Любомира Гузара, ${ }^{1}$, Киев, Украина

E-mails: ${ }^{1}$ chynchenko@gmail.com, ${ }^{2} \mathrm{HanyehBahmanfar@nau.edu.ua}{ }^{36 a r m a l e y @ i . u a ~}$

В статье рассмотрены теоретические аспекты исследования БПЛА для полетов в стратосфере, определены особенности применения нейронных сетей для разработки методики оценки их эффективности. Проанализированы алгоритм функиионирования стратосферных БПЛА в заданных условиях. Разработаны мероприятия по оптимизачии использования данных БПЛА.

Ключевые слова: нейронные сети, искусственный интеллект, БПЛА, программирование, интеллектуальные технологии, стратосфера.

\section{AUTHORS:}

Volodymyr Kharchenko (1943). Doctor of Alexander Onishchenko (1995) PhD student, Technical Sciences, Professor.

National Aviation University, Kyiv, Ukraine.

Education: National Aviation University.

Research area: management of complex sociotechnical systems, air navigation systems and automatic decision-making systems aimed at avoidance conflict situations, space information technology design, air navigation services in Ukraine provided by CNS/ATM systems.

Publications: 541.

\section{Hanyeh Bahmanfar}

Current position, $\mathrm{PhD}$ student, Junior researcher at the National Aviation University, Kyiv, Ukraine.

Education: National Aviation University Faculty of Transport, Management and Logistic Junior researcher at the National Aviation University, Kyiv, Ukraine.

Education: National Aerospace University «Kharkiv Aviation Institute», NAU «KhAI», Kharkiv,Ukraine.(2018)

Research area: Control of folding social and technical systems, aeronautical systems and systems of automatic reception of solutions, adapted to unique conflict situations, aerial vehicle design, Flight dynamics and assessment of aircraft.

Publications: 5. 